Warszawskie Studia Pastoralne UKSW

Rok XII 2017 Nr 1(34)

Natalia Smolińska

\title{
CELIBAT OSÓB DUCHOWNYCH JAKO PRZESZKODA DO ZAWARCIA MAŁŻEŃSTWA
}

Celibacy of the clergy as an obstacle to marriage

Celibat kapłański jest tematem żywo dyskutowanym na wielu płaszczyznach, między innymi psychologicznej, socjologicznej, historycznej, teologicznej czy wreszcie kanonicznej. Podsycany przez media rodzi coraz więcej ataków na Kościół katolicki. Sprawa stała się głośna zwłaszcza po medialnych skandalach seksualnych z udziałem księży. Afery te doprowadziły do powstania opinii, według której celibat połączony ze wstrzemięźliwością ma negatywny wpływ na psychikę duchowieństwa, a tym samym rodzi różne dewiacje seksualne, łącznie z narastającą liczbą księży homoseksualnych. Ponadto, prawdopodobnie właśnie celibat jest przyczyną spadku liczby powołań kapłańskich, a także porzucania przez księży stanu duchownego. Nie sposób pominąć także zagadnienia statusu prawnego osób, które porzuciły stan duchowny. Należy bowiem pamiętać, że rezygnacja z kapłaństwa nie oznacza automatycznego otrzymania dyspensy od celibatu. Osoby porzucające kapłaństwo bardzo często pozostają w związkach cywilnych, co powoduje niemożność przyjmowania przez nie sakramentów, a tym samym odsunięcie od Kościoła. Osoby te, związane szczególną więzią z Kościołem, nierzadko pragną powrotu do pełnej komunii ze Wspólnotą. Niniejsza praca pomoże przybliżyć tematykę związaną z celibatem i dyspensowaniem od obowiązku jego zachowania.

\section{Rys historyczny instytucji celibatu}

Nie sposób w tak krótkim artykule przedstawić całą historię kształtowania się celibatu kapłańskiego, dlatego najpierw nastąpi krótkie 
odniesienie do Pisma Świętego, a następnie przedstawienie trzech kluczowych momentów kształtujących instytucję celibatu.

\section{Biblijne początki celibatu}

Celibat jest instytucją, której początki sięgają czasów starotestamentalnych. W Księdze Kapłańskiej wyliczonych jest kilka warunków czystości. Jednym z powodów niezachowania tejże czystości jest „wypłynięcie nasienia” (Kpł 15, 16-17). Nieczystość ta uniemożliwiała kapłanowi spożywanie poświęconych ofiar oraz sprawowanie aktów kultu. O tej samej czystości czytamy w I Księdze Samuela, kiedy to kapłan Achimelek postawił Dawidowi i jego towarzyszom, przed udzieleniem pozwolenia na spożycie poświęconych ofiar, jeden warunek, a mianowicie brak współżycia z kobietami (1 Sm 21, 5). Kwestia nieczystości spowodowanej wydzielinami płciowymi budzi wiele dyskusji, ponieważ nie są jasne przyczyny takiego podejścia do tego zagadnienia. Wydaje się, że motywacją jest symbolizowanie przez nie utraty życial, a ponieważ Bóg jest Bogiem życia, wszystko co przywodzi na myśl śmierć jest nieczyste.

Nie ulega wątpliwości, że pomiędzy Starym a Nowym Testamentem znajdujemy elementy ciągłości, jednak należy także pamiętać, że wraz z narodzinami Jezusa Chrystusa Stary Testament został wypełniony, a między obydwoma testamentami zachodzi przytłaczająca różnica, co zauważa św. Paweł „Wobec przeogromnej chwały [Nowego Przymierza] okazało się w ogóle bez chwały to [Przymierze] (Stare), które miało chwałę częściową" (2 Kor 3,10). Biorąc pod uwagę powyższe, przykładem dla współczesnych kapłanów nie powinni być zatem kapłani starotestamentalni, ale Jezus Chrystus $^{2}$ i tak też naucza Kościół katolicki.

1 Por. G. Paximadi, Czy celibat nie jest anachroniczna pozostałościa po rytualnej czystości wymaganej od kapłanów Starego Testamentu?, w: Żonaci księża? 30 palących pytań w kwestii celibatu, red. A. Cattaneo, Wydawnictwo Bernardinum, Pelplin 2012, s. 19.

2 Por. tamże, s. 18. 
Jezus, jak wynika ze świadectwa Ewangelii, żył w bezżeństwie, nie mając dzieci. Świadomie dokonał On takiego wyboru - chociaż judaizm postrzegał taki sposób życia jako upokarzający ${ }^{3}$ - prawdopodobnie po to, aby całkowicie poświęcić się głoszeniu królestwa Bożego. Tak też zwolennicy celibatu kapłańskiego tłumaczą potrzebę jego istnienia, przekonując, że tylko żyjąc w bezżeństwie, duchowni mogą całkowicie oddać się posłudze kapłańskiej.

\section{Okres patrystyczny w historii celibatu}

Od narodzin chrześcijaństwa wstrzemięźliwość seksualna uznawana była za istotny znak rozpoznawczy tej religii. Od samego początku celibat budził wiele kontrowersji, a uczeni Kościoła spierali się w tej kwestii już w pierwszych wiekach jego funkcjonowania.

Nie sposób w tych rozważaniach nie wspomnieć o pismach św. Justyna, który pisał o nieskażonej czystości wielu starszych mężczyzn i kobiet ${ }^{4}$. Brak jednak w jego tekstach związku celibatu z kapłaństwem. Innym pisarzem chrześcijańskim, który zajmował się tą problematyką był Tertuliana, Ojciec Kościoła, dla którego argumentem za celibatem duchownych była analogia do kultów pogańskich, gdzie praktykowana była wstrzemięźliwość seksualna przez kapłanów i kapłanki ${ }^{5}$.

Należy podkreślić, że radykalizm głoszony przez Justyna jeszcze 200 lat później był piętnowany przez Kościół, który samo-kastratów traktował jak morderców i samobójców, karząc takich zakazem przyjmowania Komunii Świętej przez 3 lata, nie dopuszczając ich do święceń, a wyświęconych wyrzucając ze stanu duchownego ${ }^{6}$. Mimo takiego podejścia Kościoła do celibatu, grono zwolenników

${ }^{3}$ Por. F. Manzi, Celibat kapłański jest dyscyplina Kościoła łacińskiego czy też ma pochodzenie biblijne?, w: Żonaci księża?..., dz. cyt., s. 21.

4 Por. Justyn, Apologia, w: Pierwsi apologetycy greccy, red. J. Naumowicz, Wydawnictwo M, Kraków 2004, s. 227.

5 Por. Tertulianus, De exhortatione castitatis, PL 2, c. 930.

6 Por. G. Ryś, Celibat duchownych-punkty zwrotne w historii Kościoła, w: Stosowność celibatu $w$ relacji do kapłaństwa, red. H. Sławiński, Wydawnictwo Naukowe UPJP II, Kraków 2012, s. 126. 
idei głoszonych przez św. Justyna wciąż się poszerzało. Należeli do niego m.in. św. Ambroży, św. Augustyn, św. Hieronim.

Przeciwnikiem celibatu duchowieństwa był m.in. Wigilancjusz, kapłan i pisarz kościelny, który uważał, że biskupami mogą być tylko mężczyźni żonaci, ponadto nie powinni oni udzielać święceń wyższych mężczyznom, którzy nie są żonaci. Dodał także, że idealny kandydat do święceń powinien mieć zarówno żonę, jak i potomstwo.

Mimo ogromnej wartości dydaktycznej, jaką wnosi nauczanie Ojców Kościoła, nie stanowi ono jednak prawa kościelnego. Dyskusję dotyczącą celibatu w literaturze przedmiotu zaczyna się zazwyczaj od synodu w Elwirze, którego 33 kanon niejasno traktuje o kwestii celibatu duchownych, bowiem w dosłownym tłumaczeniu brzmi on następująco: „Zakazuje się biskupom, prezbiterom i diakonom pełniącym posługę powstrzymywać się od współżycia z żonami i nie rodzić dzieci. Kto by jednak postąpił inaczej, ma być odsunięty od honoru duchowieństwa"7. Analizując tekst kanonu, nie sposób uznać, że przepis ten nakazuje wstrzemięźliwość seksualną duchowieństwa, chyba że, jak sugerują uczeni, do naszych czasów tekst zachował się $\mathrm{w}$ formie uszkodzonej.

Dekadę po synodzie w Elwirze odbyły się synody w Arles i w Ancyrze. Ojcowie synodalni w postanowieniach z synodu w Ancyrze nie nakładają na kapłanów obowiązku zachowania wstrzemięźliwości seksualnej, a wręcz pozostawiają im wybór w tej kwestii. Jednak domagają się od diakonów i prezbiterów wyraźnej deklaracji czy chcą zawrzeć małżeństwo, czy też zachować wstrzemięźliwość. Ta ostatnia decyzja rodziła skutek odsunięcia od pełnienia posługi w przypadku zawarcia małżeństwa. Inaczej kwestię celibatu rozstrzygnął synod w Arles, którego postanowienia nakazały wstrzemięźliwość wyższym duchownym żyjącym w małżeństwie.

Obowiązku celibatu kapłańskiego nie sformułował wprost sobór nicejski z 325 r., chociaż wprowadził ograniczenie co do grona kobiet, które mogą zamieszkiwać z duchownym, a mianowicie mogły to być:

7 Tamże, s. 127. 
matka, siostra lub kobieta „poza wszelkim podejrzeniem”. Podkreślenia wymaga ostatnia kategoria osób, które mogły zamieszkiwać z kapłanami, bowiem Ojcowie synodalni, formułując zapis tego kanonu, mieli na myśli żony duchownych, a zatem nie tylko dopuszczono możliwość posiadania przez księży żony, ale także przyzwolono na wspólne zamieszkiwanie $\mathrm{z}$ nimi.

Śluby wstrzemięźliwości od współżycia dla wyższych duchownych, także w ważnym małżeństwie, zostały wprowadzone pod koniec IV w. i od tego czasu stały się normą powszechnie obowiązującą. W tym miejscu warto nadmienić, że pomimo dążeń zarówno soboru w Nicei, jak i kolejnych papieży do określenia jednej dyscypliny w materii celibatu duchownych, droga do jednolitości była jednak daleka, a same Kanony Apostolskie zawierały wiele sprzeczności w tej materii, dając jednocześnie przyzwolenie duchowieństwu na życie w związkach małżeńskich, a tym bardziej na nie zachowywanie wstrzemięźliwości seksualnej'.

\section{Okres gregoriański}

W czasach wczesnego średniowiecza w każdym spisie praw przytaczane były postanowienia starożytne odnoszące się do celibatu. Jednak obok starych regulacji zaczęły pojawiać się także nowe, które zaostrzały dyscyplinę $e^{10}$. Zasadnicze znaczenie dla nowej dyscypliny miały dopiero postanowienia I i II soboru laterańskiego z pierwszej połowy XII w. Pierwszy z wymienionych soborów odnosił się do postanowień soboru nicejskiego, zaostrzając interpretację kanonu, bowiem duchownemu nie wolno zamieszkiwać nie tylko $\mathrm{z}$ konkubiną, ale także $\mathrm{z}$ żoną ${ }^{11}$. Ponadto duchownemu nie wolno zawierać

8 Por. Sobór Nicejski I, Can. 3; tekst polski w: Dokumenty Soborów Powszechnych. Tekst grecki, łaciński, polski, t. I, red. A. Baron, H. Pietras, WAM, Kraków 2002, s. 29.

9 Por. G. Ryś, Celibat duchownych-punkty zwrotne w historii Kościoła, art. cyt., s. 134.

10 Por. tamże, s. 132.

11 Por. Sobór Laterański I, Can. 7; tekst polski w: Dokumenty Soborów Powszechnych. Tekst grecki, łaciński, polski, t. II, red. A. Baron, H. Pietras, WAM, Kraków 
małżeństwa. Nie ma jednak mowy o tym, aby małżeństwo wcześniej zawarte traciło ważność ${ }^{12}$. Sobór Laterański II orzekł, że nieważnym jest małżeństwo zawierane przez wyższych duchownych, a także wezwał wiernych do bojkotu liturgii sprawowanej przez takich kapłanów. Zapis kanonu soborowego określa, że święcenia wyższe stanowią przeszkodę do zawarcia małżeństwa, a zawarcie go powoduje utratę zarówno officium, jak i beneficium ${ }^{13}$. Przepisy te nie zamykały jednak drogi do święceń wyższych tym, którzy przed subdiakonatem zawarli małżeństwo, bowiem wystarczyło, że złożyli oni przyrzeczenie wstrzemięźliwości i mogli przyjąć święcenia ${ }^{14}$.

\section{Epoka nowożytna}

Sytuacja celibatu wyklarowała się pod koniec średniowiecza. Jasna była wtedy praktyka, że wyższe święcenia mógł otrzymać tylko celibatariusz. Stanowiło to także przyczynę sporu w dobie reforma$\mathrm{cji}^{15}$. Reformatorzy bowiem odrzucali sakramentalność małżeństwa, chociaż wyraźnie podkreślali publiczny charakter związków małżeńskich. Wykazywali oni znacznie większy liberalizm niż Kościół katolicki w odniesieniu do współżycia seksualnego, odrzucając teorię, że współżycie powinno służyć jedynie prokreacji. Wielu liderów reformacji uznawało zarówno rozwód, jak i ponowne małżeństwo. Zaskakujący jest więc fakt, że w sposób bardzo nietolerancyjny podchodzili do współżycia pozamałżeńskiego ${ }^{16}$. W kwestii celibatu duchownych wypowiedział się m.in. Luter, który uznał prawo Kościoła katolickiego w odniesieniu do celibatu za „arbitralne i tyrańskie”, co

\footnotetext{
2002, s. 123.

12 Por. tamże.

13 Por. tamże, s. 144.

14 Por. E. Friedberg, Lib. III, Tit. II: De clericis coniugatis, w: Corpus Iuris Canonici. Pars secunda: Decretalium Collectiones, Akademische Druck- u. Verlagsanstalt, Graz 1955.

15 Por. Ryś G., Celibat duchownych - punkty zwrotne w historii Kościoła, art. cyt., s. 134.

16 Por. J. A. Brundage, Law, Sex and Christian Society in Medieval Europe, University of Chicago Press, Chicago 1987, s. 551.
} 
w swoich pismach potwierdził także Kalwin ${ }^{17}$. Podobne stanowisko zajął jeden z najpoważniejszych teologów reformacji - Filip Melanchton, który pisał, że „nie możemy przyjąć tej ustawy o celibacie, ponieważ jest ona sprzeczna $z$ prawem Boskim i prawem natury i jest niezgodna $z$ samymi kanonami soborowymi"18, a dalej, że celibat jest wielkim oszustwem i że nakazuje się go tak samo często, jak nie przestrzega ${ }^{19}$. Melanchton zaznacza także, że lepsze byłoby dla kapłanów życie w sakramentalnym, czystym małżeństwie, niż w udawanej wstrzemięźliwości ${ }^{20}$.

Dalszy rozwój instytucji celibatu przyniósł Sobór Trydencki, który wprowadził w Kościele katolickim seminaria duchowne, mające za zadanie formację duchową, a zwłaszcza przygotowanie do życia w celibacie, przyszłych kapłanów ${ }^{21}$. Przełom jednak i w tym przypadku nie dokonał się automatycznie. Wiele czasu minęło, zanim seminaria duchowne zapełniły się celibatariuszami. Kanony trydenckie jednak zamknęły debatę na temat celibatu duchownych po stronie katolickiej.

\section{Instytucja celibatu we współczesnym nauczaniu Kościoła katolickiego}

Magisterium Kościoła niezmiennie przekonuje o zasadności utrzymania i przestrzegania przez kapłanów obowiązku celibatu. Rozważania na ten temat należy zacząć od norm Kodeksu prawa kanonicznego, który w kanonie 227 ustanawia, że „Duchowni obowiązani są zachować ze względu na Królestwo niebieskie doskonałą i wieczystą wstrzemięźliwość i dlatego zobowiązani są do celibatu, który jest szczególnym darem Bożym, dzięki któremu święci szafarze mogą

\footnotetext{
17 G. Ryś, Celibat, Znak, Kraków 2002, s. 99.

18 F. Melanchton, Apologia Konfesji Augsburskiej, w: Wybrane Księgi symboliczne Kościoła ewangelicko-augsburskiego, Warszawa 1980, s. 280.

19 Por. tamże, s. 289.

20 Por. tamże, s. 300.

21 Por. G. Ryś, Celibat, dz. cyt., s. 102.
} 
niepodzielnym sercem łatwiej złączyć się z Chrystusem, a także swobodniej oddać się służbie Bogu i ludziom" (kan. $277 \$ 1 \mathrm{KPK}^{22}$ ).

Głównym argumentem przeciwników celibatu jest to, że obowiązek ten nie wynika z prawa Bożego, a jedynie jest zaleceniem życia na wzór Chrystusa. Zauważają to także Ojcowie Soboru Watykańskiego II, którzy w dekrecie o posłudze i życiu kapłanów Presbyterorum ordinis zaznaczyli, że celibat jest „znakiem, a zarazem bodźcem miłości pasterskiej i szczególnym źródłem duchowej płodności w świecie. Nie jest jednak wymagany przez kapłaństwo z jego natury (...)" (PO 16) ${ }^{23}$.

$\mathrm{Z}$ uwagi na powyższe pojawia się coraz więcej głosów stawiających pod znakiem zapytania sens obowiązku celibatu duchownych. Przeciwnicy tej instytucji wskazują na zły wpływ wstrzemięźliwości na sferę psychoseksualną kapłanów, co może być powodem powstawania patologii seksualnych. Analizując jednak zagadnienie ze strony psychologicznej, wydaję się, że źródło dewiacji seksualnych leży głębiej w psychice człowieka i nie jest prawdopodobne, aby wstrzemięźliwość płciowa była ich przyczyną.

\section{Święcenia jako przeszkoda do zawarcia małżeństwa}

Oczywistym jest fakt, że obowiązki wynikające z celibatu są sprzeczne z możliwością zawarcia małżeństwa, dlatego też prawodawca kościelny usankcjonował próby zawarcia małżeństwa przez duchownych w Kodeksie prawa kanonicznego.

Przeszkoda święceń stanowi jedną z przeszkód do zawarcia małżeństwa, którą reguluje kan. 1087 KPK - „Nieważnie starają się zawrzeć małżeństwo ci, którzy otrzymali święcenia” (kan. 1087). Przeszkoda ta wiąże każdego duchownego, poczynając od diakona,

\footnotetext{
22 Codex Iuris Canonici auctoritate Ioannis Pauli PP. II promulgatus (25.01.1983), AAS 1983, nr 75, cz. II, s. 1-317; tekst polski w: Kodeks prawa kanonicznego, przekład polski zatwierdzony przez Konferencję Episkopatu, Poznań 1984 [dalej cyt.: $\mathrm{KPK} / 83]$.

${ }^{23}$ Sacrosanctum Concilium Oecumenicum Vaticanum II, Decretum de presbyterorum ministerio et vita Presbyterorum ordinis (7.12.1965), AAS 1966, nr 58, s. 991-1024; tekst polski w: Sobór Watykański II, Konstytucje, dekrety, deklaracje, Pallottinum, Poznań 2002, s. 478-507.
} 
i zarówno dla diakona, jak i prezbitera czy biskupa stanowi oddzielne źródło przeszkody rozrywającej ${ }^{24}$. Ponadto, mimo wcześniejszych założeń kodyfikacyjnych ${ }^{25}$, przeszkodą związany jest również diakon żonaty, bowiem nie może on po śmierci swojej żony zawrzeć nowego małżeństwa ${ }^{26}$. Omawiana norma ma swoje źródło w ewangelicznej radzie czystości, a umieszczając ją w Kodeksie prawa kanonicznego prawodawca pragnął podkreślić wyjątkową rolę i znaczenie zachowywania obowiązków, które wynikają z tego sakramentu. Złożenie ślubów czystości, choćby milcząco, jest koniecznym elementem do otrzymania święceń ${ }^{27}$. Ponadto sakrament ten pozostawia niezatarte znamię, które uniemożliwia zmianę uzyskanej na skutek święceń tożsamości ${ }^{28}$. Przeszkoda do zawarcia małżeństwa powstaje z chwilą ważnego przyjęcia sakramentu, a ważność określana jest na podstawie kan. 1024 i 1026, które warunkują przyjęcie święceń wyłącznie przez ochrzczonego mężczyznę (kan. 1024), który cieszy się wolnością (kan. 1026), a wolność ta konstytuuje ważność sakramentu. Trudno więc mówić o nieważności przyjętych święceń kapłańskich, chociaż nie jest to niemożliwe. Jednak w większości przypadków dla ustania tej przeszkody konieczne jest uzyskanie reskryptu Stolicy Apostolskiej dotyczącego utraty stanu duchownego oraz dyspensy od celibatu.

\section{Dyspensowanie od celibatu kapłańskiego}

Kodeks prawa kanonicznego przewiduje dwie możliwości ustania przeszkody święceń, a mianowicie nieważność orzeczoną prawomocnym wyrokiem oraz dyspensę udzieloną przez Biskupa Rzymu ${ }^{29}$.

\footnotetext{
24 Por. T. Pawluk, Prawo kanoniczne według Kodeksu Jana Pawła II, t. III, Warmińskie Wydawnictwo Diecezjalne, Olsztyn 1984, s. 136.

25 Por. W. Góralski, Małżeństwo kanoniczne, LexisNexis, Warszawa 2011, s. 122.

26 Por. W. Góralski, Kanoniczne prawo małżeńskie, Polskie Wydawnictwo Prawnicze Iuris, Warszawa 2000, s. 64.

27 Por. H. Stawniak, Celibat diakonów i prezbiterów w dyscyplinie Kościoła Łacińskiego, w: Kapłaństwo posługi, red. A. Skorupa, A. Słowikowska, Wydawnictwo KUL, Lublin 2012, s. 35.

28 Por. T. Rakoczy, Dyspensa od celibatu, „Prawo i Kościół” 2006, t. I, s. 82.

29 Por. T. Pawluk, Prawo kanoniczne według Kodeksu Jana Pawła II, dz. cyt., s. 138.
} 
W poniższym opracowaniu zostanie omówiona wyłącznie dyspensa od przeszkody święceń.

Prawo kanoniczne dopuszcza możliwość dyspensowania od przeszkód małżeńskich pochodzących z pozytywnego prawa kościelnego ${ }^{30}$. Przeszkodą pochodzącą z prawa pozytywnego są święcenia, dlatego też prawodawca uregulował możliwość zwolnienia od tej przeszkody. Przepisy odnoszące się do dyspensy od celibatu duchownych zawarte są w dwóch dokumentach Kongregacji Nauki Wiary z 14 października 1980 r.: Ordinarius competens, które zawiera normy procesowe oraz Per litteras ad universos, zawierające normy prawa materialnego. Natomiast w Kodeksie prawa kanonicznego postanowiono jedynie, że kompetentnym organem do wydawania dyspensy od celibatu jest papież (kan. 291), który kompetencję tę przekazał w 2005 r. Kongregacji ds. Duchowieństwa ${ }^{31}$. Szczególną uwagę należy zwrócić na specjalny charakter dyspensy od celibatu, który wyrażony został w dokumencie Per litteras ad universos, a stwierdzający, że w sprawach o dyspensę od celibatu należy odrzucić „wszelkiego rodzaju lekkie traktowanie problemów, które pomniejszałyby znaczenie kapłaństwa, święty charakter święceń i powagę wcześniej podjętych obowiązków"32. Z zapisu tego należy wyciągnąć wniosek, że dyspensy od celibatu nie należy uznawać za prawo przysługujące kapłanowi porzucającemu kapłaństwo. Dyspensa ta jest aktem łaski udzielanej po rozważeniu każdej sytuacji indywidualnie, na prośbę zainteresowanego ${ }^{33}$.

Model procedury zmierzającej do uzyskania dyspensy od celibatu opiera się w zasadniczym stopniu na wniesieniu prośby przez

\footnotetext{
30 Por. tamże, s. 117.

31 Por. Congregazione per il Clero, www.vatican.va/roman_curia/congregations/ cclergy/documents/rc_con_ cclergy_pro_31051999_it.html (dostęp: 02.02.2016 r.).

32 Sacra Congregatio pro Doctrina Fidei, Per Litteras ad universos, AAS 1980, nr 72, s. 1132-1135; tekst polski w: W trosce o petnię wiary. Dokumenty Kongregacji Nauki Wiary 1966-1994, Biblos, Tarnów 1995, s. 151.

33 Por. W. Kiwior, Dyspensa od celibatu prezbiterów i diakonów, „Prawo Kanoniczne” 2011, nr 3-4, 120.
} 
zainteresowanego kapłana. W dalszej części procedura przedstawia się następująco:

- przyjęcie wniosku przez kompetentnego ordynariusza;

- zawieszenie prezbitera w wykonywaniu posługi kapłańskiej;

- mianowanie instruktora sprawy i notariusza;

- instrukcja sprawy;

- przesłanie akt do Kongregacji ds. Duchowieństwa i studium sprawy;

- udzielenie dyspensy i notyfikacja reskryptu ${ }^{34}$.

Taka procedura spowodowała, że powstała spora grupa osób, które porzuciły kapłaństwo, bez zamiaru powrotu, nie uzyskawszy jednak dyspensy, co często było powodem zgorszenia wśród wiernych35. Z tego też względu papież Benedykt XVI w 2009 r. udzielił Kongregacji ds. Duchowieństwa specjalnych uprawnień w zakresie udzielania dyspensy od celibatu. Nowe normy pozwalają na uzyskanie dyspensy łącznie z deklaracją o utracie stanu duchownego, gdy kapłan porzucił posługę uporczywie, dobrowolnie i bezprawnie od ponad pięciu lat36. Wskazana wyżej możliwość jest dopuszczalna, gdy nie jest możliwe przeprowadzenie procesu w trybie zwyczajnym. Norma ta rozwiązuje specyficzny stan prawny osób, które porzuciły posługę kapłańską, ale nie prosiły o dyspensę od celibatu.

Warto także przywołać treść kan. 61: „Jeśli nie stwierdza się czegoś innego, reskrypt może być uzyskany dla drugiego, nawet niezależnie od jego zgody, i jest ważny przed jego akceptacją". Przepis ten daje Ordynariuszowi kompetencję, dzięki której w przypadku niemożliwości przeprowadzenia procesu w trybie zwyczajnym, ten może ubiegać się o reskrypt dla kapłana, który nie jest zainteresowany proszeniem o dyspensę, gdy z dochodzenia lokalnego wynika

\footnotetext{
34 Por. tamże, s. 125-138.

35 Por. M. Brzeziński, Małżeństwa byłych celibatariuszy i osób konsekrowanych, w: Małżeństwo i rodzina podstawowa troską Kościoła, red. A. Domaszk, M. Saj, Scriptum, Warszawa 2015, s. 247.

36 W. Barszcz, Przyczyny i procedury przeniesienia duchownych do stanu świeckiego na podstawie uprawnień Kongregacji ds. Duchowieństwa, „Prawo Kanoniczne” 2011, nr 3-4, s. 64.
} 
„stwierdzona niemożność obiektywna lub subiektywna, iż zainteresowany duchowny poprosi o dyspensę od obowiązków wynikających z przyjętych święceń" ${ }^{37}$. Dzięki tej kompetencji Ordynariuszowi łatwiej rozwiązać zaistniały problem i przywrócić porządek prawny, mając na uwadze także troskę o zbawienie dusz ${ }^{38}$.

Uzyskanie reskryptu wywołuje znaczące skutki prawne, bowiem oprócz utraty przynależności do stanu duchownego i przeniesienia do stanu świeckiego wraz z dyspensą od celibatu, daje także możliwość zawarcia kanonicznego związku małżeńskiego, jednak w sposób umiarkowany i bez rozgłosu ${ }^{39}$, a także pozwala na legalizację potomstwa $^{40}$.

Należy także zaznaczyć, że zaleca się, aby kapłan, który porzucił stan duchowny i został zwolniony z obowiązku celibatu, zamieszkał z dala od miejsca, gdzie jest znany jako kapłan, aby uniknąć ewentualnego zgorszenia i niezrozumienia ze strony wiernych świeckich.

\section{Podsumowanie}

Zawirowana historia instytucji celibatu nie pomaga w zrozumieniu i pełnym zaakceptowaniu obowiązku wstrzemięźliwości płciowej wymaganej od duchowieństwa. Zagadnienie to jest przedmiotem wielu refleksji, dyskusji, a nawet sporów w świecie tak liberalnie i otwarcie podchodzącym do seksualności. Nie zmienia to jednak nauczania Kościoła katolickiego odnośnie do celibatu. Magisterium Kościoła, mimo wielu naruszeń obowiązku wstrzemięźliwości przez duchownych, wciąż głosi, że jest on „jaśniejącym klejnotem korony

\footnotetext{
37 Congregazione per il Clero, L'identità missionaria del Presbitero nella Chiesa quale dimensione intrinseca dell'esercizio dei tria munera, w: Enchiridion Vaticanum 2009-2010, nr 26, s. 286-297.

38 Por. M. Stokłosa, Utrata stanu duchownego w aktualnym prawodawstwie Kościoła łacińskiego, Wydawnictwo UKSW, Warszawa 2015, s. 209-210.

39 K. Ossowski, Procedura zmierzająca do uzyskania dyspensy od celibatu w Kościele Łacińskim na prośbę prezbitera, „Kościół i Prawo” 2013, nr 2, s. 130.

40 W. Kiwior, Dyspensa od celibatu kapłańskiego: kompetencje, tytuły prawne, procedura, „Prawo Kanoniczne” 1992, nr 3-4, s. 172.
} 
Kościoła"41. Mimo wielkich nadziei, jakie robią sobie przeciwnicy celibatu kapłańskiego na zniesienie tego obowiązku, realne szanse na jego realizację są bardzo nikłe w najbliższych latach, a nawet dziesięcioleciach, bowiem Kościół zbyt pilnie chroni czystość, całkowite oddanie i upodabnianie się kapłanów do Jezusa.

\section{Streszczenie}

Opracowanie pt.: „Celibat osób duchownych jako przeszkoda do zawarcia małżeństwa" przybliża tematykę związaną z celibatem i dyspensowaniem od obowiązku jego zachowania. Tekst podzielony jest na cztery punkty. Pierwszy przedstawia rys historyczny instytucji celibatu, poczynając od czasów biblijnych aż po erę nowożytną, ukazując najważniejsze punkty zwrotne rozwoju celibatu duchowieństwa. Drugi punkt przedstawia pokrótce instytucje celibatu we współczesnym nauczaniu Kościoła katolickiego, odnosząc się do Kodeksu prawa kanonicznego oraz dokumentów Soboru Watykańskiego II, a także do nauczania ostatnich Biskupów Rzymu. Punkt trzeci artykułu przedstawia problem święceń jako przeszkody do zawarcia związku małżeńskiego, nawiązując do kanonów Kodeksu prawa kanonicznego. W czwartej części artykułu omówione jest zagadnienie dyspensowania od celibatu, $\mathrm{z}$ mocnym akcentem położonym na fakt, że dyspensa od celibatu nie jest prawem przysługującym kapłanowi porzucającemu kapłaństwo, a raczej aktem łaski udzielanej po rozważeniu każdej sytuacji indywidualnie, na prośbę zainteresowanego.

\section{Summary}

Study entitled "Celibacy as an obstacle to marriage" brings issues related to celibacy and dispensation from the obligation of his behavior. The text is divided into four points. The first presents the historical institution of celibacy ranging from biblical times through to the modern era, revealing the most important turning points in the development of celibacy of the clergy. The second point briefly describes the institutions of celibacy in the contemporary teaching of the Catholic Church, referring to the Code of

\footnotetext{
41 Paul VI, Encyclical „Sacerdotalis caelibatus, AAS 1967, nr 59, s. 657-970; tekst polski w: Paweł VI, Encyklika o celibacie kapłańskim „Sacerdotalis caelibatus”, Biblos, Tarnów 1994, s. 10.
} 
Canon Law and the documents of Vatican II and the teaching of the last Bishops of Rome. Third point of the article presents the problem of ordination as an obstacle to marriage, referring to the canons of the Code of Canon Law. In the fourth part of the article discusses the issue of dispensation from celibacy, with a strong accent on the fact that the dispensation from celibacy is not a right for the priest, who give up priesthood is rather an act of grace granted after consideration of each situation individually, at the request of the person concerned.

Słowa kluczowe: celibat, małżeństwo, przeszkoda święceń, kapłaństwo, dziewictwo

Keywords: celibacy, marriage, obstacle ordination, priesthood, virginity

\section{Bibliografia}

Barszcz W., Przyczyny i procedury przeniesienia duchownych do stanu świeckiego na podstawie uprawnień Kongregacji ds. Duchowieństwa, „Prawo Kanoniczne" 2011, nr 3-4, s. 53-76.

Brundage J. A., Law, Sex and Christian Society in Medieval Europe, Chicago 1987.

Brzeziński M., Małżeństwa byłych celibatariuszy i osób konsekrowanych, w: Małżństwo i rodzina podstawowa troską Kościoła, red. A. Domaszk, M. Saj, Warszawa 2015, s. 237-252.

Codex Iuris Canonici auctoritate Ioannis Pauli PP. II promulgatus (25.01.1983), AAS 1983, nr 75, cz. II, s. 1-317; tekst polski w: Kodeks Prawa Kanonicznego, przekład polski zatwierdzony przez Konferencję Episkopatu, Pallottinum, Poznań 1984.

Congregatione per il Clero, www.vatican.va/roman_curia/congregations/ cclergy/documents/rc_con_cclergy_pro_31051999_it.html (dostęp: 02.02.2016 r.).

Congregazione per il Clero, L'identità missionaria del Presbitero nella Chiesa quale dimensione intrinseca dell'esercizio dei tria munera, w: Enchiridion Vaticanum 2009-2010, nr 26, s. 286-297.

Corpus Iuris Canonici, Pars secunda: Decretalium Collectiones, E. Friedberg, Graz 1955.

Decrees of the Ecumenical Councils. Vol. I: Nicaea I to Lateran V, red. G. Alberigo, N. P. Tanner, London-Washington 1990.

Góralski W., Kanoniczne prawo małżeńskie, Warszawa 2000.

Góralski W., Małżeństwo kanoniczne, Warszawa 2011. 
Justyn, Apologia, w: Pierwsi apologetycy greccy, red. J. Naumowicz, Kraków 2004, s. 151-285.

Kiwior W., Dyspensa od celibatu kapłańskiego: kompetencje, tytuły prawne, procedura, „Prawo Kanoniczne” 1992, nr 3-4, s. 161-175.

Kiwior W., Dyspensa od celibatu prezbiterów i diakonów, „Prawo Kanoniczne" 2011, nr 3-4, s. 117-145.

Manzi F., Celibat kapłański jest dyscyplina Kościoła łacińskiego czy też ma pochodzenie biblijne?, w: Żonaci księża? 30 palących pytań w kwestii celibatu, red. A. Cattaneo, Pelplin 2012, s. 21-29.

Melanchton F., Apologia Konfesji Augsburskiej, w: Wybrane Ksieggi symboliczne Kościoła ewangelicko-augsburskiego, Warszawa 1980.

Ossowski K., Procedura zmierzająca do uzyskania dyspensy od celibatu w Kościele Łacińskim na prośbę prezbitera, „Kościół i Prawo” 2013, nr 2, s. 115-132.

Paul VI, Encyclical Sacerdotalis caelibatus (24.06.1967), AAS 1967, nr 59, s. 657-970; tekst polski w: Paweł VI, Encyklika o celibacie kapłańskim „Sacerdotalis caelibatus”, Biblos, Tarnów 1994.

Pawluk T., Prawo kanoniczne według Kodeksu Jana Pawła II, t. III, Olsztyn 1984.

Paximadi G., Czy celibat nie jest anachroniczna pozostałościa po rytualnej czystości wymaganej od kapłanów Starego Testamentu?, w: Żonaci księża? 30 palących pytań w kwestii celibatu, red. A. Cattaneo, Pelplin 2012, s. 17-20.

Pismo Święte. Stary i Nowy Testament w przekładzie z języków oryginalnych, red. M. Peter, M. Wolniewicz, Święty Wojciech, Poznań 2013.

Rakoczy T., Dyspensa od celibatu, w: „Prawo i Kościół” 2006, t. I, s. 79-96. Ryś G., Celibat duchownych - punkty zwrotne w historii Kościoła, w: Stosowność celibatu $w$ relacji do kapłaństwa, red. H. Sławiński, Kraków 2012, s. 125-138.

Ryś G., Celibat, Kraków 2002.

Sacra Congregatio pro Doctrina Fidei, Per Litteras ad universos (14.10.1980), AAS 1980, nr 72, s. 1132-1135; tekst polski w: $W$ trosce o petnie wiary. Dokumenty Kongregacji Nauki Wiary 1966-1994, Biblos, Tarnów 1995, s. 149-151.

Sacrosanctum Concilium Oecumenicum Vaticanum II, Decretum de presbyterorum ministerio et vita "Presbyterorum ordinis" (7.12.1965), AAS 1966, nr 58, s. 991-1024; tekst polski w: Sobór Watykański II, Konstytucje, dekrety, deklaracje, Pallottinum, Poznań 2002, s. 478-507. 
Sobór Laterański I, Canones; tekst polski w: Dokumenty Soborów Powszechnych. Tekst grecki, łaciński, polski, t. II, red. A. Baron, H. Pietras, WAM, Kraków 2002, s. 117-135.

Sobór Nicejski I, Canones; tekst polski w: Dokumenty Soborów Powszechnych. Tekst grecki, łaciński, polski, t. I, red. A. Baron, H. Pietras, WAM, Kraków 2002, s. 21-47.

Stawniak H., Celibat diakonów i prezbiterów w dyscyplinie Kościoła Łacińskiego, w: Kapłaństwo postugi, red. A. Skorupka, A. Słowikowska, Lublin 2012, s. 29-48.

Stokłosa M., Utrata stanu duchownego w aktualnym prawodawstwie Kościoła łacińskiego, Warszawa 2015.

Tertulianus, De exhortatione castitatis, PL 2.

Natalia Smolińska - magister nauk prawnych w zakresie prawa kanonicznego, specjalność kanoniczno-cywilna; tytuł naukowy zdobyła w 2013 r. na Wydziale Prawa Kanonicznego Uniwersytetu Kardynała Stefana Wyszyńskiego w Warszawie. Autorka monografii pt.: Ochrona życia w nauczaniu Kościoła $i$ w kanonicznym prawie karnym. Absolwentka Wydziału Prawa i Administracji UKSW; doktorantka Wydziału Prawa Kanonicznego UKSW. Pracownik naukowy Wydziału Prawa Kanonicznego UKSW. Prezes Koła Naukowego Utriusque Iuris działającego na WPK UKSW. Obecne zainteresowania naukowe koncentrują się na zagadnieniach związanych z kanonicznym prawem procesowym oraz kanonicznym prawem karnym. 